\title{
"WHAT GHOSTS ARE HAUNTING US TODAY?" SLAVOJ ŽIŽEK'S THE RELEVANCE OF THE COMMUNIST MANIFESTO IN POST-PANDEMIC CAPITALIST REALISM. THE REVOLUTIONARY SUBJECT AND WORK
}

\begin{abstract}
However controversial a topic, Marxist thought still remains the most complex tool for the critique of Capitalism. Derrida calls Marxism "hauntological", always reappearing as a spectre of the past, always quasipresent, but also as a potential lost future. After the dismantling of the Soviet Union and the Eastern Bloc, the relevance of The Communist Manifesto seemed to have slowly waned, in a world that adopted the tenets of Neoliberalism partly as a defense against authoritarian regimes, and partly as a mean to converge toward the countries at the forefront of the global system, that had already accrued a massive lead in economic and social development. The Covid-19 virus has shocked the world to its core, but it remains to be seen whether it has brought about a paradigm shift or it has merely accentuated some of the past problems, while also triggering a kind of forced nostalgia for the apparent normality of a system that was already ridden with issues. Mark Fisher points out that "it's easier to imagine the end of the world than the end of capitalism" (Fisher 1), thus indicating the need for criticism and measures against a neoliberal monopoly on thought itself. As for Žižek's The Relevance of the Communist Manifesto, it remains to be analyzed whether it can revive the interest in the original text, as to begin compounding a viable alternative for a postpandemic global system that does not yet seem to fully grasp that it is running out of time.
\end{abstract}

Keywords: hauntology; communist manifesto; revolutionary subject; work; Marxism.

Approximately eighteen months after the debut of the Covid-19 pandemic, the world has managed to bring itself back to some semblance of normality.

\footnotetext{
${ }^{*}$ University of Bucharest; Romania.
} 
Despite all this, "The time is out of joint", as Derrida repeats after Hamlet, it is "disarticulated" (Derrida 20); one cannot shake the feeling that something is, yet still, amiss.

As new waves of the pandemic stand continuous proof to its relentlessness, we have realized by now that "actual acquittal" (Kafka 120), in a Kafkian sense, seems to be far out of sight. We remain, thus, in a state between some sort of "apparent acquittal" and "prolongation" (Kafka 120), straddling the line between short-lived, illusory victories over the pandemic, and the burden of adapting and re-thinking our way of life in order to accommodate it.

The Relevance of the Communist Manifesto can be seen as a title meant to question rather than answer; as for Derridean hauntology, Slavoj Žižek, of all people, presumably knows that ghosts tend to live on indefinitely, especially in a world that, due to the circumstances described above, is actively haunted by a way of life that, not so long ago, was considered so unbelievably normal that it was barely due any thinking over.

Capitalist Realism is Fisher's 2009 book describing the state of the world in "Really Existing Capitalism" (Fisher 45), and serves as the main theoretical background for discussing the issues in Žižek's work. Primarily, this paper will discuss the potential creation of a revolutionary subject and the issue of work, trying to reconcile Žižek and Fisher's observations with a system shocked by the unexpected and not yet fully determinate event of Covid-19. A system onto which ideology had nonetheless inscribed the idea of a certain normality - the type that had anyway been in the scope of Žižek's critique - and that may now stand on the precipice of radical change.

\section{Whither Without Marxism?}

The central problem of this paper is twofold, with both elements stemming from the same point of origin. Firstly, the question Žižek is answering (or rather asking), is whether there is any relevance to Marx's The Communist Manifesto in the $21^{\text {st }}$ century, in a landscape supposedly changed beyond recognition since the original text was published; secondly, there is the relevance of Žižek's project itself. In other words, we know we could revisit Marx's Manifesto in 2021, rechecking its value against a new backdrop, we know that we could potentially fit in some of the ideas therein in a contemporary context, but the question is: should we? Is there anything to gain from doing this?

Derrida called the question "Whither Marxism?" an "old repetition", 
something that had been on the radar for his generation, and again was made actual in the wake of Fukuyama's declarations on the end of history (Derrida 15). Because of that, precisely due to the ubiquity and constant reappearance of the theme, it never seems out of place to revisit Marx. As did Derrida in the early '90s, Žižek is attempting to touch on similar issues.

However, a good place to start would be to answer an entirely different and opposite - question, namely: whither without Marxism? Obviously, a play on words, but also a different and possibly easier to construct critical perspective to help point out exactly what went wrong in the quasi-complete absence of any proper, tangible, Marxist measures in the past 30 years in what we call the Western World. Then again, Marx's spectres never disappeared, but were not exactly present either - as per the definition. Marxism remained a "resource for theorists of and activists for social change beyond capitalism" (Wolff 3), but nonetheless Marxist theory and theorists were repressed and marginalized (Wolff 3), even increasingly more after the fall of the Soviet Union.

As for the current Neoliberal system, from the point of view of economics, Wolff claims that it possesses "a recurring pattern of oscillation" (Wolff, 6), whereby periods of growth are followed by periods of regress or stagnation. What inevitably remains after either of these phases is the very "structure of production", by which "a small group of people [...] appropriates the surplus produced by a large, different group of hired labourers." (Wolff 6). According to statistics, between 1990 and present times (although the trend started in the late '70s), the gap between productivity and worker compensation in the US has widened exponentially (Chomsky and Waterstone 206), leaving the lower and middle classes with more and more limited hedging options with every passing economic cycle, and triggering a series of developments that carry over into other aspects of life. Wolff claims that,

The end of rising real wages confronted workers' families with a choice. They could forgo rising consumption since they lacked the rising wages to afford it. They did not do so. Rising consumption was the realization of personal hopes, the sign of social success, and the promise to one's children that had to be kept. When their wages no longer rose, workers responded by finding two other ways to continue raising their consumption. First, with real hourly wages stagnant, workers' households sent more of their members to do more hours of paid labor. Husbands, teenagers, and retired 
people did more work, and millions of housewives and mothers entered the labour markets. While these responses helped raise some additional family income, they also increased the supply of job seekers, which further undermined real wages for everyone. Increased paid labour by more members of workers' households imposed enormous personal and social costs. [...] The Federal Reserve records a total household debt in 1975 of $\$ 734$ billion. By 2006 , it had risen to $\$ 12.817$ trillion. This thirty-year debt explosion has no historical precedent. Workers depleted their savings and took on ever- increasing debt levels. By 2007, US workers were exhausted by their long labour hours, emotionally stressed by the disintegration of families and households, and extremely anxious about unprecedented and, for millions of citizens, unsustainable debt levels. The post-1970s squeezing of the American worker financed unprecedented prosperity for US capitalists. They and their associates enjoyed a new "gilded" age. (Wolff 123)

Not to dwell too much on technical economic analyses, this short overview serves only as an indicator of the origin of other issues, whether they be political, social or cultural in nature. The problem with economics, especially in Neoliberalism, is the fact that all other systems, or "fields", to engage in Bourdieusian terminology, become entangled with it and appropriate, involuntarily or not, its specific logic of functioning. As Bourdieu puts it, "The reduction of all fields to the economic field (or the political field) goes hand in hand with the reduction of all interests to the interest characteristic of the economic field." (Bourdieu 111)

Thus, the oscillation of the economy is bound to create repercussions outside its boundaries. Fisher claims that "bi-polar disorder is the mental illness proper to the 'interior' of capitalism"(Fisher 35), meaning that "its ceaseless boom and bust cycles" (idem) also extend to people and the way they are subjectivized.

Additionally, Fisher points out that this crisis was preceded and caused precisely by a Jamesonian "ironic distance" specific to postmodern capitalism (Fisher 5). Returning to the question of spectres, yet again, Francis Fukuyama had his own in mind when declaring the end of history and liberal capitalism as its final stage, but they "would be Nietzschean rather than Marxist" (Fisher 6). In this case, Nietzschean spectres would mean an "excess of self-awareness" (Fisher 
6) that would ultimately render people apathetic and, although conscious of their worsening material situation and the ideological veil put up by the capitalist class, unable or simply unwilling to react to it. Žižek claims that people "no longer believe in ideological truth; they do not take ideological propositions seriously" (Žižek, The Sublime Object 30), but rather they "know that, in their activity, they are following an illusion, but still, they are doing it'“(idem).

Returning to Marx, Some years prior to the fall of the USSR, Barzini from Coppola's The Godfather (1972) was encouraging Don Corleone to not offer his services for free, then adding: "After all, we are not communists" (02:04:002:04:02). In contemporary times, this phrase would no longer be needed. "' Really Existing Socialism"' (Fisher 7) used to be a tangible standard against which capitalist systems measured their achievements. But, since "Capital is an organism that cannot sustain itself without constantly looking beyond its boundaries, feeding off its external environment" (Hardt and Negri 224), it has "all-too successfully incorporated externality" (Fisher 8), making it impossible to imagine another type of social arrangement. This underlines the lack of a conceptual apparatus that would properly identify the problems at hand. Thus, the issues described above are not usually seen as symptoms of a failing system, but rather as necessary by-products, or better yet personal responsibility.

\section{A Revolutionary Subject?}

If we consider the 2008 financial crisis to be an inflection point, we can yet again recognize Wolff's pattern: "Periods of relatively limited state regulatory and other interventions in markets and private property repeatedly encounter and manage crises until one arrives that cannot be managed." (Wolff 6). For example, we can see that after an initial dip caused by the financial crisis, the median household selling prices in the USA has increased by roughly $50 \%$ (U.S. Census Bureau and U.S. Department of Housing and Urban Development), while the median household earnings have increased by a mere $15 \%$ (U.S. Census Bureau). This is only one instance in which the standard of living seems to be on the decline; one of many reasons why Žižek and Marx are relevant, also coupled with the changes brought about by the Covid-19 virus, that seems to have accentuated (and also made more clear) the issues of the capitalist system.

Having established a basis for our analysis of Žižek's text, we can proceed to discuss the question related to the Marxist concept of the revolutionary subject and see how and if it can relate to the more recent developments created by the 
University of Bucharest Review $\propto$ Vol. XI/2021, no. 1 (new series)

Re-writing, Re-imagining the Past(III)

pandemic. Žižek starts by challenging "Elon Musk, Bill Gates, Jeff Bezos, Mark Zuckerberg, all 'socially conscious' billionaires" (Žižek, The Relevance 3), for claiming that "capitalism as we know it' is approaching its end and advocate countermeasures such as minimal income." (Žižek, The Relevance 3). When discussing the movie Wall-E, Fisher underlines that "the film performs our anticapitalism for us, allowing us to continue to consume with impunity" (Fisher 12). Referring to the way in which the movie is critical towards consumerism, Fisher makes the case that "The role of capitalist ideology is not to make an explicit case for something in the way that propaganda does, but to conceal the fact that the operations of capital do not depend on any sort of subjectively assumed belief" (Fisher, 13). Thus, the critique of capitalism is inscribed in capitalist cultural products and discourse such as Musk's, Gates' and Bezos', but it never really means to enact change; it remains at the level of empty discourse that plays on affect and the aestheticization of moral consumption.

Furthermore, Žižek points out that "The predominant ideology today is not a positive vision of some utopian future but a cynical resignation" (Žižek, The Relevance 17). Whatever alternatives might potentially be thought of are themselves "dismissed as ideology" (Žižek, The Relevance 17), since capitalism "seamlessly occupies the horizons of the thinkable" (Fisher 8). To return to Marxist theory, this is one of the reasons Žižek himself does not think that a classic revolutionary subject can coagulate nowadays (Žižek, The Relevance 24) The possibility of that happening, quoting Wolfgang Streeck, "presupposes a degree of political control over our common fate of which we cannot even dream after the destruction of collective agency." (idem)

The pure fragmentation of society specific to postmodernism essentially alters the concept of the Lacanian Big Other. Here, Fisher gives the example of Soviet Socialism, where people knew that the system was "shabby and corrupt" (Fisher 45), but the Big Other was "deemed not to know - [...] wasn't allowed to know" (idem). Fisher's point is that the gap between "what is officially accepted, and what is widely known" (idem) is actually what allows society to function. However, nowadays the belief in a Big Other has waned; Chomsky and Waterstone discuss the existence of "common senses", rather than one singular "common sense" (Chomsky and Waterstone 6), as a result of the fragmentation of society and the emergence of echo-chambers (especially online) designed to reinforce their common group beliefs.

Adding to this, the phenomenon of commodity fetishism is another 
obstacle in the way of the emergence of a revolutionary subject. Žižek claims that "Commodity fetishism [...] is not located in our mind, in the way we (mis)perceive reality, but in the social reality itself." (Žižek, The Relevance 22), and that, quoting Marx, "commodity fetishism is 'a definite social relation between men, that assumes, in their eyes, the fantastic form of a relation between things'" (Žižek, The Sublime Object 19). The issue with commodity fetishism today is that a divergence in opinion between users of two different mobile phone brands, for example, can potentially shatter any remnant of class consciousness by moving the goalpost towards commodity fandom. Thus, essentially, class differences (and consciousness) are superseded by brand allegiance.

Though Eagleton would claim that the "middle class, in image if not in reality" is "a truly universal subject" (Eagleton 19), this is precisely the bipolar logic of capitalism at work; at the same time, the ideal image of the capitalist subject is that of the middle class bourgeoise, but there is also a "fragmenting of subjectivity in the face of the emerging entertainment industrial complex" (Fisher $25)$, as the subject is reduced to "a diffuse network of passing libidinal attachments" (Eagleton 377), which more often than not revolve around the act of consumption.

All the reasons above make it near-impossible for a real Marxist revolutionary subject to emerge; people are more in touch with the act of consumption that with the act of work, their subjectivity is fragmented, and, on top of everything, the spectre of irony makes it increasingly difficult to act and organize. As for the pandemic, it seems be the harbinger of further dissensus. The questions of vaccination or border control seem to make capitalism "return in an even stronger form" (Žižek Pandemic 97), instead of being the locus of a Badiousian caesura where a true "rare" subject (Badiou 392) emerges instead of the same objects "completely determined $[\ldots]$ by the place they occupy" (Besana $40)$.

\section{Does It Work?}

Another poignant and thoroughly important issue is the one regarding work. Apart from statistical evidence that points to the decrease in buying power and quality of life, such as the evolution of housing prices and wages presented earlier in the paper, the role and importance of work in a capitalist society are possibly facing changes. Here, a Deleuzian analysis, drawing from his short essay on societies of control, can be employed. Deleuze talks about the corporate 
system as one in which there are "new ways of handling money, profits and humans that no longer pass through the old factory form" (Deleuze 7). The new ways of handling money and profits could easily be conceptualized through what Chomsky and Waterstone call "financialization" (Chomsky and Waterstone 203), a mode of, essentially, value production that does not involve traditional commodity production and sale, but rather hinges upon operations on the stock market. A good example here would be the GME phenomenon, wherein a group of Reddit users bought massive amounts of GameStop stock, causing its price to soar and, at the same time, causing massive losses for Wall Street investment banks that had bet on its downfall. Here, we have a classic example of market manipulation causing an increase in value based solely on market mechanisms, since GME's stock did not increase in value due to higher productivity or sales, the company having been severely underperforming for quite a few years. Instead, the Deleuzian concept of "capitalism for the product" (Deleuze 6) is exemplified, the product here being artificially created, purely formal, immaterial, completely divorced from "the old factory form" (Deleuze 7).

The issue of working from home, is a good instance of humans no longer participating in traditional relations of production. At first, it would seem to be just a sign of the times, with the economy shifting towards the service sector, but it becomes increasingly clear that the very paradigm of work is shifting by the intrusion of work life into private life. As Žižek points out, even though workers are not even separated from the means of production anymore, as they themselves own them (Žižek, The Relevance 10), the problem is, firstly, that there is no such thing as a clear limit between work and life anymore. Fisher speaks about,

Training that persists for as long as your working life continues... Work you take home with you... Working from home, homing from work. A consequence of this 'indefinite' mode of power is that external surveillance is succeeded by internal policing. Control only works if you are complicit with it. Hence the Burroughs figure of the 'Control Addict': the one who is addicted to control, but also, inevitably, the one who has been taken over, possessed by Control. (Fisher 22-3)

These are precisely symptoms of Deleuzian societies of control. There is no clear schedule, no enforcement from management, only a set of internalized 
"soft" rules that emerge rather from informal corporate culture than any normative/disciplinary standards, while still discreetly being overseen by cybernetic systems that track checking in/out of work and deadline compliance. Hence, the disappearance of boundaries and the conflation/confusion between free and on duty time, dressed up as convenience, while the essential logic of employment remains the same: to create profit for the owners of the company.

Secondly, Žižek talks about the primacy of individualism and the increase in precarious work (self-employment, so-called "gigs"),

Since in our society free choice is elevated into a supreme value, social control and domination cannot be allowed to appear as infringing on the subject's freedom; they have to appear as, and be sustained by, the individuals' very experience of themselves as free. There is a multitude of forms in which this unfreedom appears in the guise of its opposite: when we are deprived of universal healthcare, we are told that we are given a new freedom of choice, namely to choose our healthcare provider; when we can no longer rely on long-term employment and are compelled to search for a new precarious position every couple of years, we are told that we are given the opportunity to reinvent ourselves and discover new, unexpected creative potentials that lurked in our personality; when we have to pay for the education of our children, we are told that we become 'entrepreneurs of the self', acting like a capitalist who has to choose freely how to invest the resources he or she possesses (or borrows) - into education, health, travel... Constantly bombarded by imposed 'free choices', forced to make decisions that we are, for the most part, not even properly qualified for. (Žižek, The Relevance 28-9)

It is already a commonplace that the exploding rise of precarious work deeply affects the conditions of collective solidarity. Precarious work deprives workers of a whole series of rights that, until recently, were taken to be self-evident in any country that perceived itself as a welfare state. Workers themselves have to take care of their health insurance and retirement options; there is no paid leave; and the future is uncertain. Besides, precarious work generates antagonism within the working class, between permanently employed and precarious workers; trade unions often tend to privilege permanent workers and it is very difficult for precarious workers even to organize themselves into a union or to establish 
another form of collective self-organization. One might have expected that this strengthened exploitation would also strengthen workers' resistance, but in fact it renders resistance even more difficult. (Žižek, The Relevance 478)

This represents a problem in itself, as an added obstacle to unionizing and demanding better workers' rights, but also brings about the normalization of precarity. "Precarious 'self-entrepreneurs'" (Žižek, The Relevance 47) are similar to precarious tenants. The problem of housing is closely knit to the problem of work, and housing seems to function by the same logic, since it is "capitalist property itself that means 'abolition' of property" (idem), in the sense that extensive ownership of property by corporations and large investors implies housing precarity for the less wealthy. The need to rent due to not having sufficient collateral for a mortgage or the risk of being evicted due to price increases are examples of it. Added to this, the idea of working from home while having an unreliable living situation completely subverts and negates the whole logic of working in the first place. Instead of work sustaining the needs of the worker, such as stable housing, food, and utilities, it is precisely the opposite. The worker pays for a temporary living space whose sole purpose is to allow him or her to simply subsist and continue in a type of cyclical process.

The Covid-19 pandemic has done much to accentuate this situation. Due to restrictions and lockdowns, work has become inextricably linked to personal life, and vice-versa. Personal space has been invaded by the corporate form, while the situation of so-called "essential" employees such as retail workers or medical staff is, indeed, increasingly exposed to precarity, in the form of health and safety issues.

The way out of all this is problematic. Žižek claims that it is only now that Marx's critique of political economy is fully actual (Žižek, The Relevance 46), but that we should stop being Marxists in order to remain faithful to Marx (Žižek, The Relevance 59). This contradiction is proof that we are actually dealing with a ghost, whose only practical purpose today is marginal guidance. The normality that has become so coveted is no more than an illusory apparition. Postpandemic Capitalist Realism is eerily similar to its pre-pandemic counterpart.

In conclusion, the ghosts haunting us today, in a (not yet) post-pandemic world, are many. It is a question of time whether Covid-19 will modify the "there is no alternative" ideology Žižek talks about (Žižek, The Relevance 18), but until 
then Marx indeed remains, dormant, somewhere. Then again, as I mentioned earlier, we are haunted by a pre-pandemic way of life, with all of its pitfalls, only because it reminds us of normality. In fact, we have been haunted by "normality" for a long time now, even before the pandemic. A normality that could be a better democracy, better laws, an ideal market, a return to traditional values, depending on who is answering. The relevance of Marx and Žižek, and Fisher's texts, and their value especially after a global crisis such as Covid-19 is, again, to reiterate and possibly spark up ideas for alternatives. Whether it be work conditions, housing, or a totally radical change in subjectivity, it should always be stated that society can do better. The greatest mistake we can make is allow the ghost of previous normality to take over only on the grounds of returning the freedoms the past months have robbed us of.

\section{Works Cited}

Badiou, Alain. Being and Event. Continuum, 2005.

Besana, Bruno. "The Subject." Alain Badiou. Key Concepts. Ed. AJ Bartlett and Justin Clemens. Acumen, 2010. 38-47.

Bourdieu, Pierre. In Other Words. Essays Towards a Reflexive Sociology. Stanford University Press, 1990.

Chomsky, Noam and Marv Waterstone. Consequences of Capitalism. Manufacturing Discontent and Resistance. Hamish Hamilton, 2021.

Deleuze, Gilles. "Postscripts on the Societies of Control." October, Vol. 59, The MIT Press, 1992, pp. 3-7. Web. 30 Sep. 2021.

$<$ http://www.jstor.org/stable/778828>

Derrida, Jacques. Specters of Marx. Routledge Classics, 2006.

Eagleton, Terry. The Ideology of the Aesthetic. Blackwell Publishers, 1990.

Fisher, Mark. Capitalist Realism. Is There No Alternative?. Zero Books, 2009.

The Godfather. Directed by Francis Ford Coppola, Paramount Pictures, 1972.

Hardt, Michael and Antonio Negri. Empire. Harvard University Press, 2000.

Kafka, Franz. The Trial. Penguin Books, 2000.

U.S. Census Bureau. "Real Median Household Income in the United States

[MEHOINUSA672N]". FRED, Federal Reserve Bank of St. Louis. Web. 30 Sep. 2021

https://fred.stlouisfed.org/series/MEHOINUSA672N

U.S. Census Bureau and U.S. Department of Housing and Urban Development. 
"Median Sales Price of Houses Sold for the United States [MSPUS]".

FRED, Federal Reserve Bank of St. Louis. Web. 30 Sep. 2021

$<$ https://fred.stlouisfed.org/series/MSPUS>

Wolff, Richard. Capitalism's Crisis Deepens: Essays on the Global Economic Meltdown 2010-2014. Haymarket Books, 2016.

Žižek, Slavoj. Pandemic!. OR Books, 2020.

---. The Relevance of the Communist Manifesto. Polity Press, 2019.

---. The Sublime Object of Ideology. Rev. ed. Verso, 2008. 